Michal Galędek

Uniwersytet Gdański

\title{
ROZPORZĄDZENIE PREZYDENTA RP Z 19 STYCZNIA 1928 R. O ORGANIZACJI I ZAKRESIE DZIAŁANIA WŁADZ ADMINISTRACJI OGÓLNEJ - PRZEŁOM W BUDOWIE USTROJU ADMINISTRACYJNEGO PAŃSTWA POLSKIEGO DOBY MIĘDZYWOJENNEJ
}

Wydanie rozporządzenia Prezydenta RP z 19 stycznia 1928 r. o organizacji i zakresie działania administracji ogólnej [dalej: rozporządzenia unifikacyjnego] (Dz.U. z 1928 r. Nr 11, poz. 86) wieńczyło kilkuletnie przygotowania do uporządkowania i całkowitego (z wyjątkiem województwa śląskiego) ujednolicenia ustroju zespolonej administracji rządowej. W latach 1919-1928 obowiązywały bowiem w poszczególnych dzielnicach różnolite akty prawne. W tym okresie funkcje unifikacyjne pełniła głównie ustawa tymczasowa z 2 sierpnia 1919 r. o organizacji władz administracyjnych II instancji, a później także rozporządzenie Rady Ministrów z 11 lutego 1924 r. w przedmiocie władz administracyjnych II instancji ${ }^{1}$, których moc obowiązującą rozciagnięto na terytorium całego kraju $\mathrm{z}$ wyjątkiem dwóch województw byłej dzielnicy pruskiej oraz autonomicznego województwa śląskiego. Jednakże regulacje zawarte w obu tych aktach miały raczej ramowy i niekompletny charakter, zaś szczegółowy ustrój normowany był przepisami wykonawczymi wydawanymi odrębnie dla poszczególnych dzielnic. Przepisy regulujące ustrój administracji powiatowej

${ }^{1}$ Dz.Pr.PP. Nr 65, poz. 395; Dz.U. Nr 21, poz. 225. 
były jednolite jedynie na terytorium byłego zaboru rosyjskiego. Ich podstawę stanowiło rozporządzenie Rady Ministrów z 28 sierpnia 1919 r. o tymczasowej organizacji powiatowych władz administracyjnych I instancji na obszarze b. zaboru rosyjskiego.

Ponadto prawodawstwo stanowione w okresie formowania się państwowości polskiej było wybitnie niedoskonałe zarówno pod względem techniki legislacyjnej, jak i częściowo niedookreślonej i niespójnej warstwy merytorycznej. Tworzono je bowiem w pośpiechu, z samego założenia jedynie na krótki okres przejściowy, z myślą, iż nie tyle w perspektywie kilkuletniej, a co najwyżej kilkunastomiesięcznej zostanie ono zastąpione kompletną ustawą ${ }^{2}$. Czas oczekiwania na trwały i spójny ustrój uległ jednak znaczącemu wydłużeniu i zakończył się dopiero wraz z wydaniem rozporządzenia unifikacyjnego. Zmitrężono przynajmniej kilka lat. Pomocnym w wyjaśnieniu powodów opóźnień jest raport tzw. „Komisji Trzech” z 1926 r., której członkowie zwracali uwagę, iż w pracy nad przebudową ustroju administracyjnego towarzyszył im „... zgodny chór głosów, które w publicystyce przemawiały za najdalej idącą reformą administracji. Każdy niemal jednak z tych głosów wykluczał od tej reformy pewną dziedzinę, którą się szczególniej interesował i którą chciał mieć nietknięta, a gdyby wszystkie te wyjątki zestawić, pokazałoby się, że mimo powszechnego żądania reformy, prawie żadna reforma praktycznie nie jest możliwa"’3. Z dużą dozą prawdopodobieństwa można przyjąć, że na taki sam opór natrafiali wszyscy pozostali inicjatorzy uporządkowania ustroju administracji lokalnej, a w rezultacie ostatecznym decydentom brakowało determinacji do przeprowadzenia kompleksowych zmian.

$\mathrm{Z}$ tych względów, oceniając rolę jaką pełniło rozporządzenie unifikacyjne, w pierwszej kolejności uwypuklić należy dwie główne jego funkcje: ujednolicającą i porządkującą. Dostrzegał to jeden z twórców reformy, ówczesny naczelnik MSW Departamentu Organizacyjnego

${ }^{2}$ Zob.: Archiwum Akt Nowych w Warszawie [dalej: AAN], Prezydium Rady Ministrów. Akta numeryczne, sygn. 10358/19, k. 9.

3 Zagadnienie reformy Administracji. Sprawozdanie Komisji powołanej przez p. Prezesa Rady Ministrów do opracowania projektu reorganizacji państwowej, «Gazeta Administracji i Policji Państwowej» [dalej: «GAiPP»] 10/1926, s. 156. 
Maurycy Jaroszyński, który zauważał, że nowo wydane rozporządzenie: „Unifikuje [...] organizację administracji w całej Polsce z wyjątkiem Śląska [...] rzeczywiście, a nie tylko formalnie, albowiem opiera ją wszędzie na jednych i tych samych ideach przewodnich. Stwarza jednolity system, którego wcześniej nie było. Istniały tylko fragmenty oparte na rozmaitych tytułach prawnych. Wiele kwestii było zupełnie nieuregulowanych. Istniało wiele niedomówień i niejasności. Pod względem merytorycznym wprowadza nowe urządzenia [...] bardzo pożądane"4. Do tych uwag dodać należy, że zręby dotychczasowego ustroju powstały w 1919 r. przed uchwaleniem konstytucji marcowej, a co za tym idzie nie w pełni realizowały zawarte w niej postanowienia.

Nie umniejszając roli ujednolicającej i porządkującej rozporządzenia unifikacyjnego, nie można jednak popaść w przesadę, uznając, że doszło do radykalnego przełomu w tej materii. Występujące we wcześniejszym okresie rozbieżności pomiędzy dzielnicami generalnie nie dotykały bowiem zasadniczych elementów istniejącego systemu. Te zaś były wspólne dla całego kraju. Na tym tle odrębnym charakterem wyróżniały się przede wszystkim (oprócz autonomicznego województwa śląskiego, które $\mathrm{z}$ racji swojego specjalnego statusu nie zostało również objęte mocą rozporządzenia unifikacyjnego) województwa byłej dzielnicy pruskiej - pomorskie i poznańskie. Odmiennie niż w pozostałych dzielnicach ich organizacja była tylko ,przystosowaniem dawnego ustroju administracyjnego pruskiego do potrzeb polskiej administracji”. Zasadnicze różnice istniejące w tych województwach wynikały $\mathrm{z}$ utrzymania $\mathrm{w}$ niektórych sprawach zasady kolegialnego współdziałania z wojewodą urzędu wojewódzkiego, współudziału czynnika obywatelskiego $\mathrm{w}$ wykonywaniu określonych czynności administracyjnych, a także $\mathrm{z}$ istnienia sądownictwa administracyjnego ${ }^{5}$.

${ }^{4}$ Organizacja władz administracji ogólnej. Wywiad dziennika „Epoka” z wiceministrem dr. Jaroszyńskim, «GAiPP» 2/1928, s. 167.

5 AAN, Ministerstwo Spraw Wewnętrznych, sygn. 24, K. Dubiel, Organizacja województw RP, 12 IV 1922, k. 28-29. Z nieścisłej redakcji przepisów ustawy tymczasowej z 2 sierpnia 1919 r. można było wyciagnąć wniosek, iż polski prawodawca przewidywał kolegialny system polskiej administracji, także w innych dzielnicach 
Natomiast prace, które można nazwać „porządkującymi”, a mające na celu usunięcie niedociagnięć organizacyjnych, bardzo wyraźnych w pierwszych latach istnienia administracji lokalnej, postępowały w zasadzie nieustannie przez cały okres oczekiwania na nowe regulacje. Zintensyfikowano je w okresie poprzedzającym wydanie rozporządzenia unifikacyjnego. Modyfikacje i udoskonalenia wdrażano czy to na mocy aktów prawa powszechnie obowiązującego, przede wszystkim rozporządzenia Rady Ministrów z 11 lutego 1924 r., czy też wydawanych na użytek wewnętrzny uchwał rządu i okólników ministerialnych. W tym okresie zainicjowano również niektóre przekształcenia realizujące zawczasu postanowienia nieprzyjętego jeszcze projektu. Wszystkie te inicjatywy dotyczyły tylko określonych zagadnień ustrojowo-kompetencyjnych, nie pretendując nawet do kompleksowego ujęcia tematu. Jednakże w przededniu wydania rozporządzenia unifikacyjnego wiele udało się już osiagnąć 6 . Fundamentalnym wyznacznikiem wprowadzanych rozwiązań były postanowienia konstytucji marcowej zawarte zwłaszcza w art. 66, w którym ustanowiono zasady zespolenia, dekoncentracji i udziału czynnika obywatelskiego w administracji. Stanęły one także u podstaw założeń rozporządzenia unifikacyjnego. Wszystkie te okoliczności pozwalają na wysunięcie tezy, iż zasady i instytucje prawne uregulowane w tym akcie stanowiły przeważnie rozwinięcie i udoskonalenie wcześniejszych inicjatyw. Podtrzymywały one dotychczasową linię rozwojową polskiej administracji lokalnej. Mimo bowiem odczuwalnych niewattpliwych mankamentów, istota ustroju administracyjnego ustanowionego w 1919 r. nie była uznawana za $\mathrm{z}$ gruntu wadliwą.

Rzeczypospolitej. W rzeczywistości jednak taka forma nie była dopuszczalna na terytorium obowiązywania tych aktów, za czym jednoznacznie opowiedziała się ówczesna doktryna. Zob tamże, k. 7.

${ }^{6}$ Treść przyszłego rozporządzenia unifikacyjnego znana była administracji lokalnej jeszcze przed jego wydaniem, zaś MSW w tym okresie zainicjowało niektóre przekształcenia zgodne z postanowieniami nie przyjętego jeszcze projektu, ujmując je w formę wewnętrznych wytycznych. Zob. R. HAUSNER, Rozporzadzenie unifikacyjne o stanowisku wojewodów i starostów jako przedstawicieli Rzqdu, «GAiPP»18/1931, s. 662 . 
Nie udało mi się precyzyjnie ustalić, z czyjej inicjatywy i w którym momencie przystapiono do prac nad opracowaniem nowego projektu. W swojej działalności reformatorskiej rząd wykorzystywał dorobek specjalnych komisji powoływanych kilkukrotnie w okresie międzywojennym w celu przygotowywania reform administracji ${ }^{7}$. Należy jednak zwrócić uwage, iż komisje urzędowały zawsze przez zbyt krótki okres czasu, aby gruntownie i kompleksowo przygotować przebudowę. Jednocześnie częstokroć złożone one były z ludzi „,z zewnątrz”, nie pracujących w odpowiednich agendach MSW, a tym samym nie mających bezpośredniej urzędowej styczności z bieżącymi problemami związanymi z wadliwą konstrukcją ustroju administracyjnego. Przede wszystkim zaś kończyły one swoją działalność, nie mając żadnego wpływu na późniejsze praktyczne wprowadzanie w życie przygotowywanych reform. Wysiłki komisji koncentrowały się także na problematyce związanej z ustrojem zarządu lokalnego. Jednakże żadna $\mathrm{z}$ nich nie uczestniczyła bezpośrednio w pracach nad reorganizacją zarządu lokalnego, której ukoronowaniem było opracowanie rozporządzenia unifikacyjnego. Ostatnie gremium, które obradowało nad koniecznymi przekształceniami przed przeprowadzeniem ujednolicenia - wspomniana już - Komisja Trzech w swoim sprawozdaniu złożonym na początku 1926 r. w ogóle nie przewidywała jeszcze wydania nowego aktu, a jedynie przygotowała cząstkową reformę, przedstawiając projekt ustawy nowelizującej ustawę tymczasową z 2 sierpnia $1919 \mathrm{r}$. i kilka innych projektów. Nie została ona wprowadzona w życie, a proponowane przez tą komisję rozwiązania w niejednym punkcie daleko odbiegały od ostatecznie przyjętych w rozporządzeniu unifikacyjnym ${ }^{8}$. Mimo niewątpliwego wykorzystania dotychczasowego dorobku czynników koncentrujących się nad przebudową administracji lokalnej, „prace przygotowawcze do zasadniczej ustawy o ustroju władz woje-

${ }^{7} \mathrm{Na}$ temat prac komisji patrz: J. PRzYGODzki, Problematyka reformy administracji w pracach rzqdowych komisji do usprawnienia administracji w II Rzeczpospolitej, «Acta Universitatis Wratislaviensis», nr 2616, seria «Prawo», 288/2004, s. 281-296.

${ }^{8}$ Zob.: Zagadnienie reformy Administracji..., s. 156-162. 
wódzkich i powiatowych" zainicjowano dopiero po zakończeniu działalności „Komisji Trzech” w 1926 r. ${ }^{9}$.

Ważnym bodźcem dla przeprowadzenia kompleksowej reformy było przejęcie władzy przez obóz sanacyjny. Z pewnością wydarzenia związane z zamachem majowym ułatwiły działanie, niwelując ryzyko odrzucenia przygotowanego projektu, bądź zbyt daleko idących modyfikacji w jego treść uzasadnionych jedynie doraźnym interesem politycznym. Obawy w tym względzie wzbudzała wyraźnie zarysowująca się w rozporządzeniu unifikacyjnym tendencja do wzmocnienia władzy wojewodów, która mogła napotkać na sprzeciw w parlamen$\mathrm{cie}^{10}$. Po uchwaleniu noweli sierpniowej podobnych komplikacji można było uniknąć, przyjmując projekty rządowe z pominięciem sejmu i senatu w drodze rozporządzenia Prezydenta z mocą ustawy. W MSW podkreślano zatem, że zastosowanie tego trybu „wysunęły na czoło” prace legislacyjne prowadzone $\mathrm{w}$ obrębie ministerstwa ${ }^{11}$. Być może nawet impuls do wdrożenia reformy w drodze wydania nowego aktu prawnego nie pochodził z zewnątrz, a z kręgów urzędniczych tego resortu, które z premedytacją mogły wyczekiwać tylko na odpowiednią chwilę, żeby przystapić do realizacji tego zadania. Niewątpliwie nadał on wraz z krystalizacją się nowego układu politycznego po objęciu władzy przez obóz Piłsudczyków i wznowieniu administracji centralnej na kształt prawa stanowionego.

MSW niezależnie od działalności komisji do reform administracji - odgrywało przewodnią rolę we wszelkich wdrażanych przekształceniach administracyjno-ustrojowych jako instytucja stale odpowiedzialna za ten zakres działania. Tam też wypracowano treść rozporządzenia unifikacyjnego, a intensyfikacja prac nad tą reformą miała związekprzebudową tegoż resortu. We wcześniejszym okresie bowiem niewątpliwą bolączką był brak należycie zorganizowanej komórki w obrębie

9 R. HAusner, Administracja Spraw Wewnętrznych w roku 1926, «GAiPP» 1/1927, s. 52 .

10 Zob. R. Hausner, Zebrania naczelników władz w województwach i powiatach, «GAiPP» 39/1926, s. 622; TENŻE, Zmiana Konstytucji, a usprawnienie administracji, «GAiPP» 9/1931, s. 314-315.

11 R. HAusner, Administracja Spraw Wewnętrznych w roku 1926..., s. 51. 
struktury ministerialnej, która stale i planowo prowadziłaby i czuwała nad nowym zarządem lokalnym. Utworzono ją dopiero wraz z przyjęciem nowego statutu organizacyjnego MSW 1 lipca 1926 r. pod nazwą Departamentu Organizacyjnego, w którym najprawdopodobniej zostały skoncentrowane prace nad projektem. Jak oceniano, na nowo „... ujęta kompetencja tego departamentu daje całość logiczną i zupełną i tworzy zeń instrument, który we właściwych rękach może istotnie rozwiązać problem organizacji administracji spraw wewnętrznych, ... a co najważniejsze utrzymać ciagłość organizacji i sprawności tak Ministerstwa, jak podległych organów w okresie czy to zmiany ministra, czy wypadków dla państwa szczególnie krytycznych"12. $\mathrm{Na}$ czele Departamentu Organizacyjnego stanął urzędnik w randze podsekretarza stanu, które to stanowisko powierzono wspomnianemu już dr. Maurycemu Jaroszyńskiemu, wybitnemu uczonemu, ówczesnemu kierownikowi Katedry Prawa Administracyjnego w Wolnej Wszechnicy Polskiej w Warszawie i specjaliście przede wszystkim od zagadnień samorządowych. Ważną rolę w przygotowaniu treści rozporządzenia unifikacyjnego odgrywał też zapewne ówczesny dyrektor Wydziału Organizacyjno-Prawnego Roman Hausner, który następnie był referentem projektu z ramienia tegoż Departamentu MSW w Radzie Prawniczej ${ }^{13}$.

Przechodząc do analizy treści rozporządzenia unifikacyjnego, po pierwsze należy stwierdzić, że utrzymał on dotychczasowy model systemu biurokratycznego przyjęty w państwie polskim w 1919 r.

12 R. Hausner, Reorganizacja Ministerstwa Spraw Wewnętrznych, «GAiPP» 29/1926, s. 474 .

${ }^{13}$ Roman Hausner pracował w MSW jako wyższy urzędnik od 1919 r., faktycznie kierując $w$ imieniu ministra kwestiami związanymi z organizacją administracji spraw wewnętrznych przez cały okres międzywojenny. Oprócz bieżącej działalności, która znajdowała wyraz m.in. w setkach sygnowanych przez niego (z upoważnienia ministra) okólników i innych pism instruujących aparat administracyjny, był on też autorem wielu publikacji poświęconych problematyce administracyjno-ustrojowej, w tym szczególnie artykułów naukowych ukazujących się na łamach «GAiPP» i monografii wydawanych przez MSW. W ten sposób Hausner odcisnął trwałe piętno nie tylko na treści rozporządzenia unifikacyjnego, ale na całokształcie przemian w organizacji polskiej administracji dokonywanych w okresie międzywojennym. 
Jakkolwiek więc na określenie zespolonej administracji rządowej akt ten wprowadził nowy termin ,administracji ogólnej”"14, to nadal reprezentowali ją jednoosobowo ${ }^{15}$ wojewodowie w województwach i starostowie $\mathrm{w}$ powiatach ${ }^{16}$. Zniesiono jednocześnie elementy kolegialności występujące w byłym zaborze pruskim. Organy administracji ogólnej nieodmiennie występowały w dwojakim charakterze: zwierzchników zespolonej administracji rządowej (funkcja administracyjna) oraz przedstawicieli rządu (funkcja polityczna). W zakresie funkcji administracyjnej rola rozporządzania unifikacyjnego ograniczała się do ścisłego określenia dotychczas już wykonywanych kompetencji i zadań, czego do tej pory nie uczyniono ${ }^{17}$. Utrzymano też obowiązujące dotąd reguły podległości służbowej i osobowej. W zakresie szczegółowych kompetencji wynikających $\mathrm{z}$ prawa administracyjnego materialnego

${ }^{14}$ Organy administracyjne określano w rozporządzeniu unifikacyjnym mianem „władz państwowych administracji ogólnej” pierwszej, bądź drugiej instancji. Była to odmienna konwencja terminologiczna niż w aktach prawnych wydanych przed unifikacją administracji, w myśl których starostowie byli ,zwierzchnikami władzy administracyjnej" pierwszej, a wojewodowie drugiej instancji.

15 R. Hausner, Pierwsze dwudziestolecie administracji spraw wewnętrznych, Warszawa 1939, s. 80. Zasadę monokratyczności polskiej administracji ujęto przede wszystkim w formule, iż organy administracji ogólnej „działają pod osobistą odpowiedzialnością, samodzielnie i jednoosobowo", której w aktach prawnych obowiązujących przed unifikacją zasadniczo zabrakło.

${ }^{16}$ Rozporządzenie unifikacyjne rozróżniało starostów powiatowych, grodzkich oraz utrzymało odrębny urząd starosty morskiego w Gdyni. Termin „starosta powiatowy” zastapił formę ,starosta” obowiązującą pod rządami rozporządzenia Rady Ministrów z 28 sierpnia 1919 r. Natomiast urzędy starostów grodzkich ustanowiono w miastach, którym rozporządzenie unifikacyjne nadało status powiatów miejskich oraz w dzielnicach Warszawy.

${ }^{17} \mathrm{~W}$ charakterze zwierzchnika administracji ogólnej wojewoda występował w województwie, a starosta analogicznie w powiecie, jako: 1) organ zarządzający, orzekający, rozstrzygający i stawiający wnioski, 2) służbowy zwierzchnik władz, urzędów i organów, 3) organ nadzoru nad ich działalnością, 4) przełożony zatrudnionych w nich funkcjonariuszy z prawem ich mianowania, przenoszenia i zwalniania, 5) urzędowy przewodniczący wszystkich organów kolegialnych powołanych do współdziałania w działach zespolonych, 6) odpowiedzialny wykonawca zleceń ministrów (wojewoda) bądź wojewody (starosta). Ponadto w rozporządzeniu unifikacyjnym wyszczególniono kompetencje, które służyły wykonywaniu tych funkcji. 
nadal obowiązywało wcześniejsze prawodawstwo. Jako że było ono częściowo odrębne dla poszczególnych dzielnic, wciąż decydowało o dzielnicowej różnorodności w tej sferze. Ów partykularyzm utrzymał się zresztą - choć w sukcesywnie ograniczanym zakresie - do końca okresu międzywojennego ${ }^{18}$.

Analizując treść rozporządzenia unifikacyjnego. w pierwszej kolejności należy się skoncentrować na odpowiedzi na kluczowe w praktyce pytanie, w jakim stopniu akt ten stwarzał warunki dla kształtowania silnego i niezależnego statusu wojewodów. W nauce pokutuje bowiem teza - skądinąd słuszna, acz nie w pełnym zakresie udokumentowana iż wraz z ujednoliceniem ustroju wzmocniono także ich pozycję prawną. Decydowało o niej kilka głównych czynników. Pierwszym z nich był zakres zespolenia. W rozporządzeniu unifikacyjnym nie uległ on zmianie w stosunku do wcześniejszego okresu, a zatem katalog dziedzin zarządu podległych wojewodom (a także według analogicznej reguły starostom) formalnie nie został rozszerzony ${ }^{19}$. Podobnie jak w innych, także i w tym aspekcie wskazać jednak należy na ważną funkcje porządkująca, jaką spełniał ten akt wobec nieprzejrzystego i budzącego wattpliwości stanu prawnego i faktycznego w poprzednim okresie. Po raz pierwszy bowiem precyzyjnie wyszczególniono, które dziedzi-

18 Tamże,s. 78-79. Wzakresieregułpostępowaniaadministracyjnegorozporządzenie unifikacyjne utrzymało obowiązującą od 1923 r. zasadę dwuinstancyjności, zgodnie z którą w pierwszej instancji zasadniczo orzekał starosta, a odwołania rozpatrywał wojewoda, którego decyzja była ostateczna.

19 Maurycy Jaroszyński zauważał, że: „Dotychczas ścierały się u nas dwa skrajne prądy dotyczące wzajemnego stosunku lokalnych władz rozmaitych resortów. Jeden, będący refleksem dawnych urządzeń austriackich, dążył do zupełnego podporządkowania wojewodzie i staroście wszystkich działów administracji pod każdym względem, drugi zaś - do zupełnej równorzędności wszystkich działów. W omawianym rozporządzeniu zwyciężyła zasada pośrednia. Zupełne zespolenie uznano za niewłaściwe w normalnych czasach, zwłaszcza wobec znacznego rozbudowania poszczególnych działów administracji pod względem rzeczowym i organizacyjnym, które widzimy po wojnie zarówno w Polsce jak i zagranicą. Takie zespolenie bowiem kolidowałoby z postulatem odpowiedzialności kierowników oraz z racjonalną organizacją pracy. Z drugiej strony potępiono także system zupełnej równorzędności, dający w praktyce chaos, odbijający się dotkliwie na całej polityce wewnętrznej i na skórze obywateli" - Organizacja władz administracji ogólnej..., s. 167. 
ny podlegają zwierzchnictwu wojewody, a które są spod niego wyłączone $^{20}$. Minister spraw wewnętrznych Felicjan Sławoj Składkowski propagandowo stwierdzał na forum sejmowej Komisji Budżetowej, iż w ten sposób zostało zapewnione ścisłe i harmonijne współdziałanie wszystkich działów administracji rządowej ${ }^{21}$. Do oficjalnych wypowiedzi ministra należy jednak podejść z pewnym dystansem, gdyż pozostawienie dotychczasowego zakresu zespolenia oznaczało utrzymanie dość szerokiego katalogu wyłączeń, podczas gdy jego uzasadnienie nie było w pełni przekonujące. Już przy okazji dyskusji po wydaniu rozporządzenia unifikacyjnego pojawiały się głosy, iż właściwość rzeczowa administracji zespolonej została $\mathrm{w}$ nim ujęta zbyt wąsko ${ }^{22}$, węziej aniżeli proponowała choćby „Komisja Trzech”23. Zwrócić bowiem należy uwagę, że w świetle zawartej w konstytucji marcowej dyrektywy administracja miała „w miarę możności” zostać skupiona ,w jednym urzędzie pod jednym zwierzchnikiem". Mimo to dopiero w latach trzydziestych zakres zespolenia uległ poszerzeniu o nowe gałęzie ${ }^{24}$, a w sferach rządowych dominujące stawało się przeświadczenie, że: „Jednolitość kierunku polityki rządowej w województwach i powiatach, jednolitość poczynań organizacyjno-oszczędnościowych wymaga bezwarunkowo skupienia całej władzy w województwie i w powiecie w jednym ręku"25.

${ }^{20}$ Zakres zespolenia został ustalony w rozporządzeniu unifikacyjnym w sposób pozytywny. Wyszczególniono bowiem dziedziny wyraźnie nim objęte, tym sposobem definiując też pojęcie ,administracji ogólnej”.

${ }^{21}$ Przemówienie ministra sprawwewnętrznych Sławoja Składkowskiego wygłoszone w Komisji Budżetowej Sejmu dn. 10.V r. 1928, «GAiPP» 5/1928, s. I.

22 R. HAusner, Organizacja i zakres działania władz administracji ogólnej, «GAiPP» 2/1928, s. 102. Pogląd Hausnera o zbyt wąskim zakresie zespolenia administracji rządowej z końca lat dwudziestych kontrastuje $\mathrm{z}$ opinią tegoż autora z początku lat dwudziestych, że zakres zespolenia był zakreślony szeroko i w stopniu wystarczającym TENŻE, Organizacja władz administracyjnych, «GAiPP» 26/1922, s. 381.

${ }_{23}$ Zagadnienie reformy Administracji..., s. 156-157.

${ }^{24}$ Znaczące zmiany wprowadzono w życie dopiero 1 stycznia 1934 r., likwidując niezespolone urzędy: dróg wodnych, techniczne oraz ziemskie. Ich zadania przejęły urzędy wojewódzkie i starostwa.

${ }_{25}$ R. Hausner, Poczynania organizacyjno-oszczędnościowe $w$ Polsce $w$ latach 1918-1934, Warszawa 1934, s. 47. 
Po drugie, poszerzeniu zakresu działania zespolonej administracji rządowej służyła realizacja konstytucyjnej zasady dekoncentracji. Nakazywała ona wyposażyć władze lokalne w jak najszerszy katalog kompetencji decyzyjnych, zakładając jednocześnie, iż ograniczy to rolę ministerstw do pełnienia ogólnych funkcji kierowniczych i inspekcyjnych, co poprawi jakość wykonywania tych zadań ${ }^{26}$. Rola rozporządzenia unifikacyjnego $\mathrm{w}$ tym zakresie polegała na udzieleniu upoważnienia ministrom do przenoszenia w drodze rozporządzeń swych uprawnień w określonych sprawach na rzecz wojewodów, jak również uprawnień wojewodów na rzecz starostów oraz innych władz niższego szczebla ${ }^{27}$. Taką możliwość przewidziano co prawda także we wcześniejszym okresie, ale w stosunku do generalnych pełnomocnictw uregulowanych w rozporządzeniu unifikacyjnym była ona w znaczący sposób ograniczona ${ }^{28}$. Do skrupulatnej realizacji tej zasady przywiązywano też dużą wagą, tym bardziej, że prowadzone w okresie przed unifikacją administracji działania dekoncentracyjne przyniosły niewielkie efekty, co wynikało zarówno z ograniczonych możliwości prawnych, jak i faktycznej niechęci do ich przeprowadzenia na szerszą skalę ${ }^{29}$.

${ }^{26}$ Zob. R. HAusner, Nowe zasady organizacji i urzędowania ministerstw, «GAiPP» 37/1926, s. 584-585. Patrz szerzej: W. CZAPLIŃsKI, Zagadnienie dekoncentracji, «GAiPP» 12/1931, s. 429 i n.

27 Zob. Organizacja władz administracji ogólnej..., s. 168; R. Hausner, Poczynania..., s. 47-48.

${ }^{28}$ Do dekoncentracji upoważniała ministrów ustawa tymczasowa z 2 sierpnia 1919 r., jednakże mogła ona objąć jedynie delegacje kompetencji ze szczebla centralnego na wojewódzki i tylko w obrębie działów zaliczonych do administracji ogólnej, a ponadto dotyczyła uprawnień przysługujących ministrom według stanu prawnego obowiązującego przed wejściem w życie tejże ustawy.

29 Jednym z problemów ustroju administracyjnego, którego nie potrafiono przezwyciężyć w okresie przed unifikacją administracji, był niewłaściwy podział czynności między władze lokalne i centralne. Stanowił on rezultat przyznania ministerstwom na etapie ich tworzenia zadań ,przechodzących o wiele ich siły”, a w późniejszym okresie ,... biernego oporu biur ministerialnych strzegących zazdrośnie swego zakresu działania". W rezultacie, jak zauważano w sprawozdaniu Komisji Trzech, wskutek nieprzeprowadzonej akcji dekoncentracyjnej wynikała: „... szkoda... dla ministerstw, które przeładowana drobnymi sprawami uginają się pod ich ciężarem, a nie mogą 
Reformatorzy byli zaś przeświadczeni, że dekoncentracja ma: „,... doniosłe znaczenie dla sprawności działania aparatu administracyjnego, ponieważ odciąży wyższe instancje od załatwiania spraw stosunkowo drobnych i pozwoli na szybkie i ostateczne załatwianie spraw w instancjach niższych, a więc lepiej i bardziej bezpośrednio znających stan faktyczny" 30 . W rezultacie na podstawie rozporządzenia unifikacyjnego i wydanych do niego przepisów wykonawczych kilkukrotnie udało się przeprowadzić akcje dekoncentracyjne, co prowadziło do dalszego wzmacniania pozycji wojewodów kosztem organów centralnych, w mniejszym zaś stopniu starostów względem wojewodów.

Po trzecie, kompleksowo unormowano uprawnienia wojewodów, a pośrednio i starostów związane z wykonywaniem przez nich funkcji reprezentantów rządu. Regulacje te miały doniosłe znaczenie, na co zwracali uwagę sami twórcy projektu. Maurycy Jaroszyński przekonywał wręcz, iż opracowany akt usuwał istotne braki ,z punktu widzenia rządzenia państwem". Były one charakterystyczne dla okresu przed unifikacją administracji ${ }^{31}$, kiedy to według dyrektora Departamentu Organizacyjnego: „Częściowo już według dotychczasowych przepisów, a w większej mierze według praktyki, wojewodowie i starostowie uznani byli za przedstawicieli całego rządu w województwie względnie w powiecie. To »przedstawicielstwo« nie było jednak prawnie ściśle określone ani wyposażone $\mathrm{w}$ odpowiednie rygory. Toteż $\mathrm{w}$ wielu

się oddać swemu istotnemu zadaniu. Szkoda również dla województw, które zamiast rozstrzygać sprawy, muszą pisać o każdej z nich obszerne sprawozdania i wnioski do ministerstw. Szkoda wreszcie dla obywateli, którzy w tych sprawach musząudawać się aż do stolicy państwa, zamiast mieć je załatwione bliżej w województwie. Dekoncentracja stanowczo przeprowadzona usunie niepotrzebną pisaninę i balast biurokratyczne" Zagadnienie reformy Administracji..., s. 158.

30 R. Hausner, Poczynania..., s. 42.

31 Kompetencje związane $\mathrm{z}$ funkcją przedstawiciela rządu po raz pierwszy zostały uregulowane w uchwałach Rady Ministrów z 6, 9 i 18 sierpnia 1923 r. w sprawie reorganizacji administracji państwowej, a wprowadzone w życie częściowo mocą rozporządzenia Rady Ministrów z 11 lutego 1924 r., częściowo zaś w drodze aktów wewnątrzadministracyjnych, bądź zmiany prawodastwa regulującego ustrój porządnych dziedziń administracji specjalnej. 
wypadkach sprowadzało się ono do czczego tytułu bez treści" ${ }^{32}$. Stan ten uległ zmianie dopiero wraz z wydaniem rozporządzenia unifikacyjnego, które nie tylko porządkowało zadania i kompetencje związane z funkcją reprezentanta rządu, ale znacząco je rozszerzało. Jednocześnie w akcie tym uwzględniono możliwość przyznania analogicznych uprawnień starostom, jakkolwiek ich wpływ na niezespolone działy administracji był „normalnie znacznie mniejszy niż wojewody”33.

Podstawowa grupa kompetencji związanych z funkcją przedstawiciela rządu służyła celom koordynacyjnym związanym z odpowiedzialnością wojewodów i starostów za uzgodnienie i zapewnienie jednolitości działań całej administracji lokalnej w myśl „stanowiska ogólnej polityki rządu"34. Ustalając katalog tych uprawnień uznawanych za „najważniejszy cel zespolenia”, nawiązywano do rozwiązań prawnych przyjętych $\mathrm{w}$ okresie przed ujednoliceniem administracji. Dopiero jednak rozporządzenie unifikacyjne wraz z przepisami wykonawczymi umożliwiło ich pełną implementację. Dotyczyło to zebrań naczelników organów administracji niezespolonej pierwszej bądź drugiej instancji organizowanych pod przewodnictwem odpowiednio starostów lub wojewodów ${ }^{35}$. Ponadto na mocy rozporządzenia unifikacyjnego przyznano wojewodom prawo do żądania wyjaśnień od kierowników urzędów niezespolonych w każdej sprawie, w której wy-

32 Organizacja władz administracji ogólnej..., s. 167.

33 Tamże, s. 167-168.

${ }^{34}$ Zob.: R. HAusner, Organizacja i zakres działania władz..., s. 101; TEnżE, Rozporzqdzenie o stanowisku wojewodów i starostów jako przedstawicieli rzqdu, «GAiPP»18/1931, s. 662.

35 Stanowisko wojewodów i starostów jako przedstawicieli Rzq̨u, «GAiPP» 19/1931, s. 719; Organizacja władz administracji ogólnej..., s. 167. Instytucję zebrań kierowników drugiej instancjiustanowiono na podstawie rozporządzenia Rady Ministrów z 11 lutego 1924 r. W stosunku do dotychczasowych regulacji nowością wzmacniającą pozycję wojewody na zebraniach, było $\mathrm{m}$. in. postanowienie, iż udział poszczególnych urzędników na danym zebraniu będzie uzależniony od indywidualnego zaproszenia wojewody. Natomiast względem zebrań powiatowych rola rozporządzenia unifikacyjnego sprowadzała się do ustawowego uregulowania tej instytucji funkcjonującej do tej pory jedynie na podstawie uchwały rządowej z 13 stycznia 1926 r. Zob.: R. HAUSNER, Zebrania naczelników władz w województwach i powiatach..., s. 624. 
konywali oni swoje funkcje przedstawicieli rządu ${ }^{36}$. Na urzędników tych nałożono też obowiązek uzgadniania $\mathrm{z}$ wojewodą projektów zarządzeń natury ogólnej, który istniał także przed unifikacją administracji, ale nie na podstawie powszechnie obowiązujących przepisów i w związku z tym w ograniczonym zakresie ${ }^{37}$. Do nowych instytucji należało zaś prawo do uczestnictwa wojewody bądź starosty w co do zasady wszystkich zwoływanych w podległych im okręgach kolegialnych organach administracyjnych z możliwością zabierania głosu poza kolejnością mówców, a także objęcia przewodnictwa w obradach. Następna grupa uprawnień przedstawicieli rządu umożliwiała im sprawowanie nadzoru nad sprawami osobowymi funkcjonariuszy państwowych ze stanowiska interesów bezpieczeństwa państwa oraz porządku i spokoju publicznego ${ }^{38}$. Oceniano, iż w tym zakresie rozporządzenie unifikacyjne przyznało wojewodom ,poważne środki” do prowadzenia polityki personalnej, jakkolwiek uprawnienia te przysługiwały im już we wcześniejszym okresie ${ }^{39}$. Odrębny zbiór kompetencji uregulo-

${ }^{36}$ W wypadkach szczególnie ważnych, gdy zwłoka zagrażała interesowi publicznemu, wojewoda był uprawniony do osobistego wglądu, a wyjątkowo do bezpośredniej ingerencji w tok spraw tych instytucji. Prawo do żądania wyjaśnień mogło zostać przekazane starostom jednak bez możliwości upoważnienia ich do osobistego wglądu w tok spraw instytucji państwowych. Zob. Organizacja władz administracji..., s. 167.

${ }^{37}$ Kompetencja ta wynikała z uchwał Rady Ministrów z 6, 9 i 18 sierpnia 1923 r. oraz wydanych na ich podstawie zarządzeń wewnętrznych poszczególnych ministerstw.

38 Do uprawnień osobowych należały kompetencje do: 1) wydawania poufnych opinii o kandydatach przyjmowanych do służby państwowej; 2) żądania usunięcia ze stanowiska urzędników administracji niezespolonej lub przenoszenia ich na inne miejsca służbowe; 3) opiniowania kandydatur na stanowiska samoistne lub kierownicze w urzędach administracji niezespolonej. Negatywne zdanie wojewody w tej sprawie bądź żądanie usunięcia lub przeniesienia danego funkcjonariusza na inne miejsce służbowe powodowały, iż w przypadku nieosiagnnięcia porozumienia z odpowiednim niezespolonym organem terytorialnym, sprawę rozstrzygał ostatecznie właściwy minister. Uprawnienia te przyznano tylko wojewodom, którzy mogli je jednak delegować na rzecz starostów za zgodą ministra spraw wewnętrznych.

39 R. Hausner, Rozporzadzenie o stanowisku wojewodów i starostów..., s. 665. Kompetencje $\mathrm{z}$ tego zakresu przysługiwały wojewodom w okresie przed unifikacją administracji na podstawie uchwały Rady Ministrów z 9 sierpnia 1923 r. oraz wydanego na jej podstawie rozporządzenia rządowego z 11 lutego $1924 \mathrm{r}$. 
wany po raz pierwszy dopiero w rozporządzeniu unifikacyjnym wynikał z nałożenia na wojewodów odpowiedzialności za uzgadnianie działalności całej administracji, jak również czynników społecznych z potrzebami obrony państwa. Oceniano, że przyznano im w ten sposób daleko idące możliwości wglądu w organizację i sposób urzędowania niezespolonych działów administracji ${ }^{40}$. $Z$ drugiej strony zobowiązano zaś wojewodów do czuwania nad należytym uwzględnianiem interesów gospodarczych województwa przez władze wojskowe ${ }^{41}$. Na koniec wreszcie w rozporządzeniu unifikacyjnym rozwiano wszelkie występujące do tej pory wątpliwości, przesądzając, iż w każdej sprawie wynikającej ze stanowiska wojewody (ale nie starosty) jako przedstawiciela rządu służy mu prawo do bezpośredniego porozumiewania (w tym także przedkładania spostrzeżeń i wniosków) ze wszystkimi władzami, zarówno centralnymi, jak i lokalnymi.

Wydaje się, że znaczące w stosunku okresu przed unifikacją rozwinięcie środków oddziaływania przysługujących administracji ogólnej względem dziedzin niezespolonych było możliwe dopiero w nowych warunkach politycznych po zamachu majowym, gdyż we wcześniejszym okresie mogło ono napotykać na zdecydowany opór w parlamencie $^{42}$. Bezpośrednio po wydaniu rozporządzenia unifikacyjnego Roman Hausner podkreślał, że tym sposobem przedstawiciel rządu uzyskał na tyle rozległe kompetencje, iż wynagradzały one zbyt sze-

40 Stanowisko wojewodów i starostów jako przedstawicieli Rząu..., s. 721.

${ }^{41}$ R. HAusner, Rozporzqdzenie o stanowisku wojewodów i starostów..., s. 665.

42 Przeprowadzenie reformy mocą rozporządzenia prezydenckiego pozwoliło uniknąć potencjalnych protestów na forum parlamentu, z którymi rząd spotkał się po przyznaniu wojewodom cząstkowych tylko uprawnień względem administracji niezespolonej na mocy rozporządzenia Rady Ministrów z 11 lutego 1924 r. W zgłaszanych wówczas interpelacjach zarzucano mu: „,.. chęć poddania działów niezespolonych, a szczególniej szkolnictwa pod supremację wojewody i wprowadzenia tym samym »polityki do szkoły«". Broniąc się przed tą krytyką, twórcy reformy podnosili wówczas, iż: „W rzeczywistości chodziło rządowi nie o narzucenie linii politycznej przez wojewodów, a o uzgodnienie linii działania wszystkich resortów, które zresztą jako zależne od samego Rządu, zasadniczą linię polityki powinni mieć jedną i tę samą". Zob. TENŻE, Zebrania naczelników władz w województwach i powiatach..., s. 622. 
roki zakres dziedzin wyłączonych spod ich zwierzchnictwa, a więc nie objętych zasadą zespolenia ${ }^{43}$. Z perspektywy kilku lat dostrzegł jednak, iż uprawnienia wojewodów w tym zakresie „... pozornie dość znaczne, zostały jednak obwarowane bardzo licznymi zastrzeżeniami i wyjątkami. Stało się tak dlatego, ażeby pozyskać zgodę wszystkich ministerstw na wydanie tego rozporządzenia. W rezultacie wojewoda nie ma prawa wydawania żadnych zarządzeń w stosunku do działów niezespolonych, a może jedynie opiniować, stawiać wnioski, informować się, doradzać, protestować itd. Niemniej przeto w sytuacjach naprawdę trudnych i wymagających stanowczych wystąpień główny ciężar odpowiedzialności spada na barki wojewody [...] Takie postawienie sprawy jest nieszczere, utrudnia uzgodnienie działalności całej administracji rządowej między sobą i z zasadniczą linią polityki rządu, której wykładnikiem w poszczególnych jednostkach terytorialnych może być tylko jedna osoba" ${ }^{4}$. Kompetencje zostały bowiem określone w taki sposób, aby nie prowadziły do podporządkowania wojewodom organów administracji niezespolonej, w szczególności, aby nie mogli oni wydawać orzeczeń i zarządzeń w zakresie wykraczającym poza zakres zespolenia. Zasadniczo ich wpływ musiał się zatem ograniczać do zgłaszania dezyderatów, których wprowadzanie w życie uzależnione było od uzgodnienia z właściwym kierownikiem urzędu administracji niezespolonej ${ }^{45}$. Sytuacja uległa pewnej zmianie wraz z wydaniem przez Radę Ministrów rozporządzenia z 2 lipca $1931 \mathrm{r}$. o stanowisku wojewodów i starostów jako przedstawicieli Rządu ${ }^{46}$. Tym sposobem MSW udało się po długotrwałych i żmudnych negocjacjach międzyministerialnych przełamać opór innych resortów i skorzystać z upoważnienia do rozszerzenia uprawnień administracji ogólnej w tym zakresie ${ }^{47}$.

${ }^{43}$ R. Hausner, Organizacja i zakres działania władz..., s. 102.

${ }^{44}$ R. Hausner, Zmiana Konstytucji, a usprawnienie administracji..., s. 314-315.

${ }^{45}$ R. HAusner, Organizacja i zakres działania władz..., s. 103. Brak porozumienia powodował, iż sprawę rozstrzygał ostatecznie odpowiedni minister resortowy.

46 Dz.U. Nr 66, poz. 546.

${ }^{47}$ R. HAusner, Rozporzqdzenie o stanowisku wojewodów i starostów..., s. 657. 
Po czwarte, rozporządzenie unifikacyjne usunęło „dotkliwe braki w dotychczasowej kompetencji władz administracji ogólnej”, za jaką uznawano pozbawienie wojewody prawa do wydawania powszechnie obowiązujących rozporządzeń porządkowych ${ }^{48}$. W okresie przed unifikacją administracji akty te - pod nazwą rozporządzeń policyjnych - mogli wydawać tylko wojewodowie poznański i pomorski ${ }^{49}$. Spodziewano się zatem, że rozciagnięcie tego uprawnienia na teren całego kraju umożliwi władzom uregulowanie i dostosowanie do lokalnych potrzeb ,wielu szczegółów z zakresu bezpieczeństwa i porządku publicznego, nieunormowanych przez ustawy i rozporządzenia władz centralnych" ${ }^{50}$.

Podsumowując, wydaje się, że wydanie rozporządzenia unifikacyjnego, jakkolwiek realnie wpływało na wzrost pozycji prawnej wojewodów, a pośrednio także starostów, to nie zmieniało jej radykalnie. Przy czym umocnieniu władzy nie tyle służyło samo dość umiarkowa-

${ }^{48}$ R. Hausner, Organizacja i zakres działania władz..., s. 106; Organizacja władz administracji ogólnej..., s. 167. Do wydawania przepisów powszechnie obowiązujących wykonujących ustawy upoważniała wojewodów konstytucja marcowa. Obok rozporządzeń porządkowych wojewodowie mogli także wydawać, analogicznie jak przed unifikacją administracji, rozporządzenia wykonawcze. W przeciwieństwie do nich rozporządzenia porządkowe można było wydawać powołując się na ogólne cele ochrony, bezpieczeństwa, spokoju i porządku publicznego w wypadkach nieunormowanych osobnymi przepisami.

49 Natomiast w województwach byłego zaboru rosyjskiego takie uprawnienie mogło przysługiwać wojewodom, tylko, o ile w określonym szczegółowym zakresie przewidywała to ustawa bądź rozporządzenie ministerialne. Nadto przypadki takie miały miejsce sporadycznie.

${ }^{50}$ K. Dubiel, Rozporzadzenia porzadkowe, «GAiPP» 3/1929, s. 81-82; R. HAUSNER, Wykonanie rozporzqdzenia Prezydenta Rzeczypospolitej o organizacji $i$ zakresie działania władz administracji ogólnej, «GAiPP» 9/1928, s. 768. Uprawnienia przyznane wojewodom w tym zakresie rodziły pewne obawy, skoro w okólniku ministra spraw wewnętrznych nr 30 z 5 marca 1928 r. zarządzono, aby wydawanie przez wojewodów rozporządzeń wykonawczych i porządkowych odbywało się aż do odwołania tylko po przedłożeniu projektu MSW, które musiało wyrazić na nie zgodę. Wprowadzenie tej dyrektywy uzasadniano „koniecznością pewnego uzgodnienia działalności wojewodów w zakresie wydawania rozporządzeń w obrębie poszczególnych obszarów prawnych". 
ne wzbogacenie katalogu kompetencji o zupełnie nowe uprawnienia, co uporządkowanie i uzupełnienie już wcześniej funkcjonujących rozwiązań. Przede wszystkim jednak nie sama warstwa normatywna decydowała o silnej pozycji wojewodów i starostów, stwarzała ona tylko dla niej podatny grunt. O jego wykorzystaniu przesądzała zaś polityczna wola zagwarantowania samodzielności działania strukturom lokalnym. Tutaj wymaga odnotowania, że w okresie rządów pomajowych władze centralne ze szczególnym uwzględnieniem MSW powszechnie deklarowały taką wolę, a i wcześniejszy okres nie był pozbawiony podobnych oświadczeń. Już wówczas zarysowywała się wyraźnie tendencja do przeniesienia punktu ciężkości w zarządzaniu państwem na organy administracji terytorialnej. Determinowały ją nie tylko omówione powyżej konstytucyjne dyrektywy dekoncentracji i zespolenia, ale też przekonanie, iż taki system sprzyja prawidłowemu funkcjonowaniu administracji, a w szczególności umożliwia realizację prawnie nieusankcjonowanego rządowego programu regionalistycznego. Oficjalnie głoszonym hasłom zwykle jednak towarzyszył bierny opór ministerstw, nieskorych do wyzbywania się władzy. Spowalniał on, ale nie wstrzymywał stale postępującego procesu. Minister spraw wewnętrznych Felicjan Sławoj Składkowski niebezzasadnie przekonywał zatem jeszcze na rok przed wydaniem rozporządzenia unifikacyjnego, iż administrację zespoloną cechuje: „... daleko posunięta samodzielność wojewodów i starostów w stosunku do władz centralnych, prawo i obowiązek - zwłaszcza o ile chodzi o wojewodów - ostatecznego regulowania wielu bardzo ważnych problemów życiowych bez uciekania się o decyzję do władz centralnych i bez opierania się na szczegółowych instrukcjach tych władz, a także wielki zakres władzy, wyrażający się między innymi zarówno w możności wpływania na całą administrację państwową, chociażby niezespoloną formalnie w urzędach wojewodzińskich i starościńskich, jak i w możności oddziaływania na administrację samorządową przez organiczne wplecenie wojewodów i starostów w ustrój samorządu terytorialnego"s1.

51 W sprawie organizacji urzędów wojewódzkich i starostw, «GAiPP»10/1927, s. 936. 
$\mathrm{Z}$ drugiej jednak strony $\mathrm{w}$ okresie przed unifikacją administracji także można było mówić o silnej pozycji i niezależności wojewodów, a częściowo też i starostów, co w dużej mierze wynikało z pewnej słabości ministerstw. W ich obrębie co prawda samodzielnie załatwiano rozliczne sprawy, które można było delegować na rzecz administracji terytorialnej, to jednak $\mathrm{z}$ tego względu stanowily one instytucje przeciążone i nienajlepiej zorganizowane. W efekcie nie wykonywano należycie funkcji kierowniczych, a w szczególności brakowało programów działania oraz skutecznego systemu kontroli, które „wiązałyby ręce administracji lokalnej”, dając im pole do faktycznej samodzielności w prowadzonej działalności. Natomiast okres po unifikacji charakteryzował się już z kolei stabilizacją i stopniowym doskonaleniem organizacji ministerialnej, w tym też systemu nadzoru nad prowincją. Pojawiła się także tendencja, szczególnie widoczna w drugiej połowie lat trzydziestych, do coraz bardziej szczegółowego kreślenia linii politycznej, formułowanej w coraz spójniejszych, ale i częstokroć coraz bardziej drobiazgowych wytycznych. Silniej więc wykorzystywano podległość wojewodów względem władz centralnych, która tylko formalnie nie uległa zmianie, a z pewnością zaczynała mocniej niż w latach dwudziestych wiązać ręce strukturom lokalnym. Dodać przy tym należy, że na podobnych zasadach potęgowała się również zależność starostów i innych władz od wojewodów. Finalnie więc choć z prawnego punktu widzenia pozycja administracji ogólnej uległa niewątpliwemu wzmocnieniu, czemu sprzyjały postanowienia rozporządzenia unifikacyjnego, a i faktycznie też nie osłabła, to w praktyce obserwowaliśmy tu proces, na który składały się w równym stopniu różnorodne czynniki prawne i faktyczne. W ujęciu horyzontalnym bowiem wzrost pozycji prawnej wojewodów determinowany z jednej strony prawnie usankcjonowaną akcją dekoncentracyjna, z drugiej polityką regionalistyczną hamowany był poprzez stale udoskonalane instrumentarium służące realizacji zasady hierarchicznego podporządkowania organów lokalnych względem szczebla centralnego. Natomiast niewątpliwe wydaje się wzmocnienie pozycji wojewodów i starostów w ujęciu wertykalnym, z racji obdarzenia administracji ogólnej spójnym systemem środków oddziaływania na władze niezespolone oraz uporządkowa- 
nego, a w późniejszym okresie rozszerzającego się zakresu zespolenia bezpośredniego.

Przechodząc do innych ważkich aspektów ustroju administracji ogólnej uregulowanych w rozporządzeniu unifikacyjnym, należy zwrócić uwagę głównie na organizację urzędów wojewódzkich i problematykę udziału czynnika obywatelskiego. W odniesieniu do pierwszego z tych zagadnień akt ten nie wprowadzał nowatorskich rozwiązań, a kontynuował prowadzoną od dłuższego czasu przez MSW, ale postępującą z oporami, akcję racjonalizacji i uproszczenia struktur administracyjnych. Podstawowe instytucje uregulowane w rozporządzeniu unifikacyjnym funkcjonowały już zatem w poprzednim okresie, w szczególności potwierdzono dotychczas obowiązujący podział urzędów wojewódzkich na wydziały, a te zaś na oddziały jako jednostki łączące „w miarę możności sprawy jednorodne pod względem prawnym i faktycznym". Ponadto ujęto w ramy prawne dyrektywę, którą MSW od dłuższego już czasu próbowało wprowadzić w życie, aby maksymalnie zredukować liczbę tychże jednostek organizacyjnych. Ilość wydziałów miała zatem ograniczać się do ich „niezbędnej ilości”, zaś podział wydziałów na oddziały miał być przeprowadzany tylko w razie „koniecznej potrzeby”. Natomiast wśród szczegółowych rozwiązań w założeniu doniosłe znaczenie posiadało - przygotowywane już od pewnego czasu - wyodrębnienie w każdym urzędzie wojewódzkim wydziału ogólnego, w którym skupiać się miał całokształt spraw organizacyjnych urzędu ${ }^{52}$. Natomiast $w$ praktyce duże znaczenie miała regulacja nakazująca wojewodom gruntowne uporządkowanie struktury urzędów wojewódzkich poprzez przygotowanie i opublikowanie dla nich statutów organizacyjnych i szczegółowych podziałów czynności ${ }^{53}$. Ich wprowadzanie w urzędach wojewódzkich znacząco popra-

${ }^{52}$ Zob. R. Hausner, Pierwsze..., s. 80.

${ }^{53} \mathrm{~W}$ statutach organizacyjnych należało ściśle ustalić zakres działania poszczególnych jego komórek oraz zasady odpowiedzialności zatrudnionych w nich funkcjonariuszy. Natomiast szczegółowe podziały czynności miały służyć wyczerpującemu wyliczeniu kategorii spraw wynikających z obowiązujących przepisów, a załatwianych w urzędach wojewódzkich. Oba dokumenty wzajemnie się więc uzupełniały. Zob. Okólnik ministra spraw wewnętrznych $n r 200$ do wszystkich wojewodów w sprawie 
wiły organizację wewnętrzną administracji. W okresie przed unifikacją administracji brakowało bowiem zarówno „szczegółowych i jasnych podziałów czynności”, jak i „wyraźnego ustalenia zakresu aprobaty i odpowiedzialności", bez których - według słów zawartych w jednym z okólników ministra spraw wewnętrznych - „nie dało się pomyśleć należytego funkcjonowania urzędów wojewódzkich" ${ }^{54}$. Faktycznie akcja porządkowania struktur i ujmowania ich w ramy statutów organizacyjnych i podziałów czynności rozpoczęła się już kilka lat przed wydaniem rozporządzenia unifikacyjnego i byłaby zapewne wdrażana niezależnie od tego, czy znalazłaby swoje odzwierciedlenie w treści tego aktu. Nie stanowiło też nowej zasady upoważnienie wojewodów do samodzielnego kształtowania wewnętrznej organizacji podległych im urzędów, gdyż analogiczne rozwiązanie zawarto już w rozporządzeniu Rady Ministrów z 11 lutego 1924 r. ${ }^{55}$. Prawo do elastycznego dopasowywania struktur administracyjnych do miejscowych potrzeb opierało się na założeniu, że odpowiednią wiedzę w tym zakresie posiada jedynie lokalny urzędnik. Regulacja ta także mogła przesądzać o silnej i niezależnej pozycji wojewodów. W rzeczywistości jednak samodzielność wojewodów została - podobnie jak w okresie przed unifikacją administracji-znacząco ograniczona szczegółowymi dyrektywami udzielanymi przez władze centralne z nadrzędną kierowniczą rolą $\mathrm{MSW}^{56}$. Doprowadziły one do znacznego ujednolicenia struktu-

statutów i szczegółowych podziałów czynności urzędów wojewódzkich z 23 listopada 1931 r., Dz.Urz.MSW Nr 12, poz. 250.

54 W sprawie organizacji urzędów wojewódzkich i starostw..., s. 937.

55 R. HAusner, Organizacja i zakres działania władz..., s. 104.

${ }^{56}$ Oprócz licznych zarządzeń określających wewnętrzną strukturę urzędów wojewódzkich podstawowe znaczenie w tym zakresie posiadało rozporządzenie ministra spraw wewnętrznych z 13 sierpnia 1931 r. o organizacji urzędów wojewódzkich oraz trybu załatwiania spraw w tych urzędach, jak również ramowy statut organizacyjny wydany dla urzędów wojewódzkich, a stanowiący wzorzec dla statutów wydawanych przez poszczególnych wojewodów. Mimo wszystkich tych wytycznych, częstokroć bardzo drobiazgowych, MSW przynajmniej w początkowym okresie deklarowało, iż określa jedynie ogólne zasady, pozostawiając wojewodom swobodę w kształtowaniu szczegółów organizacyjnych. Zob. W sprawie organizacji urzędów wojewódzkich i starostw..., s. 936. 
ry urzędów wojewódzkich, w pewnym stopniu przecząc ideom przyświecającym twórcom rozporządzenia unifikacyjnego, które zakładały różnorodność organizacyjną. $Z$ drugiej jednak strony ten sposób postępowania wynikał z samej treści tego aktu, bo to on właśnie zobowiązywał ministra spraw wewnętrznych do wydania w porozumieniu z zainteresowanymi ministrami przepisów dotyczących organizacji aparatu podległego wojewodzie. W rezultacie w latach trzydziestych nastąpiło usztywnienie i ujednolicenie wewnętrznej struktury urzędów wojewódzkich w całym państwie ${ }^{57}$.

W zakresie wewnętrznej organizacji starostw rozporządzenie unifikacyjne przesądzało jedynie, iż z formalnego punktu widzenia nie będą się one dzielić na jednostki organizacyjne, w szczególności charakteru takiego nie będą miały referaty, które ipso facto w okresie przed unifikacją administracji stanowiły w urzędach powiatowych wyodrębnione komórki ${ }^{58}$. W pozostałym zakresie rola tego aktu sprowadzała się do zobowiązania ministra spraw wewnętrznych, aby w porozumieniu z zainteresowanymi ministrami wydał szczegółowe przepisy ujednolicające organizację starostw oraz tryb załatwiania spraw w tych urzędach $^{59}$. Zadanie to - którego wykonanie zainicjowało MSW jeszcze przed wydaniem rozporządzenia unifikacyjnego - miało istotne znaczenie wobec istniejącej w okresie przed unifikacją administracji róż-

${ }^{57}$ Zob. R. Hausner, Rewizja przepisów o reorganizacji urzędów wojewódzkich i starostw, cz. 1, Warszawa 1938, s. 42. W latach trzydziestych - odmiennie niż przed unifikacją administracji - pozytywnie oceniano zasadę sztywnej organizacji urzędów wojewódzkich, uznając że sprawdziła się ona, obowiązując formalnie w latach 19191924, a faktycznie także w okresie 1924-1931.

58 Rozporządzenie unifikacyjne jednoznacznie przesądziło, iż przez referaty zarówno w starostwach, jak i urzędach wojewódzkich należy rozumieć jedynie grupę spraw, które w miarę możliwości miały łączyć sprawy jednorodne pod względem prawnym, względnie faktycznym.

${ }^{59}$ Odpowiednie wytyczne zawarto wpierw w okólniku nr 25 z 28 lutego 1928 r., finalnie zaś uregulowano w rozporządzeniu z 30 czerwca 1930 r. W sprawie wewnętrznej organizacji starostw oraz trybu ich urzędowania. Przepisy te $z$ jednej strony upodabniały ustrój urzędów powiatowych w skali kraju, z drugiej zobowiązały wojewodów do opracowania w ich ramach statutów i szczegółowych podziałów czynności, które w obrębie województw ustalały jednakową co do zasady wewnętrzną organizację starostw. 
norodności w ustroju starostw. Gwarantowała ona starostom swobodę w przydzielaniu zadań podległemu im personelowi, co umożliwiało dostosowywanie organizacji urzędów powiatowych do miejscowych potrzeb oraz kwalifikacji i liczebności urzędników. System ten był jednak krytykowany za uciążliwy dla mieszkańców brak przejrzystości, bądź zwykły chaos wynikający z niedostatecznej troski o uporządkowanie pracy urzędu przez czynniki lokalne ${ }^{60}$.

Obok wojewodów i starostów istniały liczne kolegia partycypujące $\mathrm{w}$ podejmowaniu decyzji administracyjnych. W tym zakresie rola rozporządzenia unifikacyjnego była znacząca, gdyż zagadnienie to szczególnie pilnie wymagało uporządkowania wobec zagmatwanego i chaotycznego systemu obowiązującego przed unifikacją administracji. Po pierwsze zatem, akt ten ustalał ścisłą regułę, iż kolegialne sposoby załatwiania spraw jako wyjątek od zasady jednoosobowości mogły wynikać jedynie z wyraźnie określonej podstawy prawnej. Po drugie, skomasowano nadmierną ilość różnorodnych kolegiów funkcjonujących w poprzednim okresie. Do urzeczywistnienia obu tych celów służyło ustanowienie rad i wydziałów wojewódzkich oraz powiatowych. W okresie przed unifikacją zbliżone w swoim charakterze rady wojewódzkie funkcjonowały jedynie w województwach centralnych $^{61}$. Natomiast wydziały wojewódzkie były zupełnie nową instytucją o dość szerokim zastosowaniu, aczkolwiek o mieszanym składzie, w którym czynnik obywatelski był skutecznie neutralizowany przez czynnik urzędniczy. Z kolei funkcje analogicznych rad i wydziałów powiatowych pełniły organy samorządu powiatowego, które to rozwiązanie zamierzano zastosować także w województwie po utworzeniu samorządu na tym szczeblu ${ }^{62}$. Istnienie tych kolegiów, podobnie

${ }^{60}$ Por. Tamże, s. 35-37.

${ }^{61}$ Rola rad wojewódzkich funkcjonujących w województwach centralnych nie uległa zmianie po wydaniu rozporządzenia unifikacyjnego, choć dopracowano szczegóły organizacyjne. Natomiast w województwach wschodnich przed unifikacją administracji do zorganizowania rad nie doszło, mimo że istniała podstawa prawna do ich powołania. W byłym zaborze austriackim nowe kolegia weszły po części w miejsce tzw. Tymczasowego Wydziału Samorządowego. Z kolei w województwie pomorskim i poznańskim, gdzie funkcjonował samorząd wojewódzki oraz w autonomicznym województwie śląskim nie utworzono tych kolegiów.

${ }^{62}$ R. Hausner, Pierwsze..., s. 80. 
jak i innych rad przewidzianych przez przepisy, realizowało jedną z idei przewodnich rozporządzenia unifikacyjnego, jaką była „tendencja do pewnego rodzaju uspołecznienia administracji”, a zarazem wykonywało konstytucyjną dyrektywę udziału czynnika obywatelskiego w administracji, która polegała na wykonywaniu zadań z zakresu administracji rządowej przez wybieranych przez społeczeństwo reprezentantów. Powołanie do życia kolegiów nie osłabiało pozycji wojewodów i starostów w nadmiernym stopniu. W praktyce bowiem ze względu na dość ograniczone kompetencje - pozostawały one pod przemożnym wpływem zwierzchnika administracji. Niepełna decentralizacja, a szczególnie brak samorządu wojewódzkiego, jak również instytucjonalne włączenie starostów w struktury samorządów powiatowych, przy słabości samorządu terytorialnego ograniczały możliwości oddolnego ograniczenia zakresu władzy administracji rządowej.

Wśród innych instytucji, bądź rozwiązań znaczącym novum z punktu widzenia formalnego było zaliczenie do władz administracji ogólnej „organów komunalnych, które spełniały zadania administracji ogólnej w zakresie ustalonym przez przepisy prawne". W okresie przed unifikacją administracji władze samorządowe, jakkolwiek wykonywały zadania zlecone, to jednak nie posiadały takiego statusu. Ponadto rozporządzenie unifikacyjne przewidziało możliwość delegacji kompetencji starościńskich na rzecz organów samorządu powiatowego - prezydentów miast, wydziałów powiatowych, zarządów miast wydzielonych oraz zarządu m.st. Warszawy. Rozporządzenie unifikacyjne ustanawiało też kategorię nowych powiatów, tzw. powiatów miejskich. Status ten z mocy prawa otrzymywały wszystkie miasta, których liczba ludności przekroczyła 75000 mieszkańców, a niezależnie od tego Rada Ministrów uzyskała upoważnienie, aby tworzyć powiaty miejskie również w mniejszych miejscowościach ${ }^{63}$. Ponadto Warszawie nadano rangę województwa, podczas gdy w okresie przed unifikacją posiadała ona status powiatu.

${ }^{63}$ Jako że wszystkie miasta, które w okresie przed unifikacją administracji posiadały już charakter powiatów (Bydgoszcz, Kraków, Lwów, Łódź, Poznań i Wilno), spełniały ten warunek, oznaczało to utrzymanie w nich stanu dotychczasowego. Dodatkowo zaś status powiatu miejskiego uzyskały cztery inne ludne miasta - Białystok, Częstochowa, Lublin i Sosnowiec. 
Podsumowując, należy zwrócić uwagę na rolę rozporządzenia unifikacyjnego jako czynnika stymulującego dalszą reformę administracji. Rola ta nie mniej doniosła niż inne opisywane jego funkcje - ujednolicająca i porządkująca. Sami twórcy tego aktu zaznaczali wręcz, że moment jego wydania jest dopiero poczattkiem okresu prac przygotowawczych nad zasadniczą reformą całej administracji publicznej ${ }^{64}$, jakkolwiek w interesującej nas sferze ustroju zarządu lokalnego stanowił on niewatpliwie przełomowe osiagnięcie. Stworzył on podstawę, na której mogła rozwijać się polska administracja terytorialna. $\mathrm{Z}$ drugiej bowiem strony, co do większości instytucji uregulowanych w rozporządzeniu, był on aktem ramowym, wyznaczającym tylko kierunki dla przyszłej przebudowy administracji ogólnej. Celowi temu służyły liczne zawarte w jego treści delegacje ustawowe na rzecz Rady Ministrów i poszczególnych jej członków, z których obficie korzystano. W swych dalszych działaniach reformatorskich rząd cieszył się zatem dużą swobodą zagwarantowaną mu postanowieniami rozporządzenia unifikacyjnego, uprawniającymi go do rozwijania przepisów w nim zawartych i określania sposobu ich wykonania. Z ramienia władz centralnych nad realizacją zadania przebudowy administracji czuwało przede wszystkim MSW, które było odpowiedzialne zarówno za opracowanie projektów aktów prawnych wprowadzających nowe rozwiązania, jak i na bieżąco nadzorowało implementację ustanowionych już regulacji i dookreślało ich treść w drodze wewnętrznych zarządzeńn ${ }^{65}$. Udział w tych działaniach miały także władze lokalne ${ }^{66}$.

${ }^{64}$ R. Hausner, Poczynania..., s. 33. Wydając rozporządzenie unifikacyjne, wyjaśniano, iż z całościowym przeprowadzeniem reformy rząd wstrzymał się jedynie ze względu na niezakończenie prac nad nową konstytucją oraz organizacją samorządu terytorialnego.

${ }_{65}$ W 1928 r. powołano przy MSW Komisję dla Usprawnienia Administracji Publicznej działającą pod kierunkiem Maurycego Jaroszyńskiego aż do 1933 r. Jej propozycje reformy miały kompleksowy charakter, stanowiąc próbę całościowego wypracowania polskiego modelu administracji publicznej.

${ }^{66}$ MSW stale konsultowało projektowane zmiany z administracją wojewódzką reprezentowaną przez wicewojewodów, zobowiązując ją do sporządzania i nadsyłania własnych propozycji i opinii dotyczących konkretnych przedsięwzięć. Ze swojej 
W pierwszym etapie bezpośrednio po wydaniu rozporządzenia unifikacyjnego szczególne znaczenie miała kompetencja rządu do wydawania rozporządzeń uzgadniających, przejściowych i wykonawczych niezbędnych do przystosowania dotychczasowej organizacji administracji do nowego ustroju ${ }^{67}$. Okres ten zakończył się na początku lat trzydziestych wydaniem kilku ważnych rozporządzeń opracowanych przez MSW ${ }^{68}$. Podsumowując te dokonania na początku 1932 r., ówczesny premier Aleksander Prystor oceniał, iż: „Stan administracji państwowej, pomimo niezaprzeczonego postępu, osiagnniętego w ostatnich kilku latach, wykazuje wiele jeszcze niedomagań. Wyrażają się one w istniejącej do dziś jeszcze nadmiernej odrębności resortów, w nadmiernej koncentracji nie tylko czynności kierowniczych, lecz i wykonawczych, w niejasnym rozgraniczeniu kompetencji wskutek tego w zbyt częstej wielotorowości przy spełnianiu tych samych lub analogicznych zadań, w nieodpowiednim podziale terytorialnym, w ogól-

strony wicewojewodowie angażowali do tej pracy zainteresowane komórki urzędów wojewódzkich i starostw.

${ }^{67}$ Po wejściu w życie rozporządzenia unifikacyjnego utrzymano moc obowiązującą części przepisów wykonawczych do ustawy tymczasowej z 2 sierpnia 1919 r., które nie były sprzeczne zjego regulacjami. Były one sukcesywnie zastępowane unormowaniami odpowiednich aktów wykonawczych do rozporządzenia unifikacyjnego, ostatecznie tracąc moc po wydaniu rozporządzenia Rady Ministrów z 13 sierpnia 1931 r. w sprawie wewnętrznej organizacji urzędów wojewódzkich oraz trybu ich urzędowania.

${ }^{68}$ Należały tutaj: rozporządzenie Rady Ministrów z 19 marca 1928 r. w sprawie powiatów miejskich (Dz.U. $\mathrm{Nr} 45$, poz. 426), rozporządzenie ministra spraw wewnętrznych z 28 marca 1928 r. w sprawie wojewódzkich i powiatowych organów kolegialnych administracji ogólnej (Dz.U. Nr 46, poz. 453), rozporządzenie Rady Ministrów z 5 lipca 1928 r. o organizacji i zakresie działania władz administracji ogólnej na obszarze miasta stołecznego Warszawy (Dz.U. Nr 72, poz. 647), rozporządzenie Rady Ministrów z 5 lipca 1928 r. w sprawie wydawania dzienników wojewódzkich (Dz.U. Nr 72, poz. 648), rozporządzenie ministra spraw wewnętrznych z 30 czerwca 1930 r. w sprawie wewnętrznej organizacji starostw oraz trybu ich urzędowania (Dz.U. Nr 55, poz. 464), rozporządzenie Rady Ministrów z 2 lipca 1931 r. o stanowisku wojewodów i starostów jako przedstawicieli Rządu (Dz.U. Nr 66, poz. 546), rozporządzenie ministra spraw wewnętrznych z 13 sierpnia $1931 \mathrm{r}$. w sprawie organizacji urzędów wojewódzkich oraz trybu załatwiania spraw w tych urzędach (Dz.U. Nr 76, poz. 611). 
nym przeroście administracji państwowej, w nadmiernej ilości władz i urzędów wszystkich resortów i instancji, w nadmiarze pośrednich szczebli hierarchicznych (zwłaszcza jeśli chodzi o władze centralne) i w nadmiarze etatów zarówno pod względem rzeczowym, jak i jakościowym. Przyczyny tych niedomagań, tkwiące w warunkach, w jakich powstał się i rozwijał aparat administracyjny Polski, były różne... Wynik był jeden: zbyt mała sprawność aparatu państwowego w stosunku do kosztów jego utrzymania, obciążających budżet państwa. Do naprawy tego stanu sprzecznego $\mathrm{z}$ racjonalnymi zasadami organizacyjnymi, niełatwo było doprowadzić. Poza trudnościami, wynikającymi z niejednostajnego ustawodawstwa, każda próba naruszenia stanu posiadania poszczególnych resortów, czy zmiany usztywnionych już schematów administracyjnych, napotyka na różnorodne, zrozumiałe skądinąd opory. Toteż dopóki budżet na to pozwalał, opory okazywały się silniejszymi od zamierzeń. Podejmowane niejednokrotnie próby dawały w wyniku tylko materiały i opracowania raczej teoretyczne, stanowiące pion pracy kilku kolejnych komisji dla usprawnienia administracji. Dopiero konieczność bezwzględnych kompresji budżetu ułatwiła przełamanie oporów i umożliwiła realne podjęcie reformy"69.

W kolejnym etapie prac udało się przeprowadzić kilka częściowych reform polegających na uproszczeniu systemu administracyjnego, przyjęcie nowych zasad biurowości, zwiększeniu zakresu zespolenia, dekoncentracji kompetencji, czy też unifikacji samorządu terytorialnego. Przede wszystkim jednak na podstawie szeroko zakrojonych prac w dużym stopniu zakończono przygotowywanie kompleksowej przebudowy całej administracji rządowej, w której cząstkowe zmiany wzajemnie się uzupełniały, tworząc wewnętrznie spoisty system ${ }^{70}$. Ciagle

${ }^{69}$ Sprawozdania Stenograficzne Sejmu RP, Warszawa 1932, s. LXVI/10-11, Protokót 66 posiedzenia Sejmu RP, 9 III 1932.

${ }^{70} \mathrm{~W}$ związku z tymi reformami dokonano kilkunastu zmian treści rozporządzenia unifikacyjnego, z których najważniejsze dotyczyły: 1) zawężenia uprawnień organów administracji ogólnej jako reprezentantów rządu w stosunku do administracji rządu (ustawa nowelizacyjna z 21 lutego 1930 r., Dz.U. Nr 17, poz. 124), 2) zmiany zakresu kompetencji administracji względem samorządu terytorialnego oraz przepisów o udziale i organizacji czynnika obywatelskiego (ustawa z 23 marca 1933 r. o częścio- 
jeszcze zauważano, że we wszystkich sferach ustrojowych zarządu państwowego było niezmiernie wiele do zrobienia, a niektóre reformy jak w kwestii podziału administracyjnego, czy organizacji nadzoru i kontroli nie zostały nawet zainicjowane. Na tych podstawach zakładano, $i z ̇$ w połowie lat trzydziestych rozpocznie się okres ,wprowadzania w życie nowego ustroju oraz zrealizowania projektów administracji państwowej w zastosowaniu do zasad nowej Konstytucji"71, który przyniesie ostateczną stabilizację w zakresie organizacji administra$\mathrm{cji}^{72}$. Nie zdołano jednak tych planów urzeczywistnić przed wybuchem Drugiej Wojny Światowej ${ }^{73}$.

wej zmianie ustroju samorządu terytorialnego, Dz.U. Nr 35, poz. 294), 3) zespolenia urzędów ziemskich (rozporządzenie Prezydenta z 27 października 1933 r. o zespoleniu urzędów ziemskich z władzami administracji ogólnej i organizacji komisji ziemskich, Dz.U. Nr 85, poz. 635), 4) zmiany pozycji prawnej wicewojewodów (rozporządzenie nowelizacyjne Prezydenta z 12 czerwca 1934 r., Dz.U. Nr 80, poz. 743 oraz rozporządzenie ministra spraw wewnętrznych z 9 maja 1935 r. w sprawie zastępstwa wojewodów, Dz.U. Nr 38, poz. 264), 5) dekoncentracji (rozporządzenie Prezydenta z 28 grudnia 1934 r. o unormowaniu właściwości władz i trybu postępowania w niektórych działach administracji państwowej, Dz.U. Nr 110, poz. 976), 6) podporządkowanie wojewodów w zakresie funkcji reprezentantów rządu prezesowi Rady Ministrów (ustawa konstytucyjna z 23 kwietnia 1935 r., Dz.U. Nr 30, poz. 227). Tak znaczna liczba nowelizacji doprowadziła do opracowania jednolitego tekstu rozporządzenia unifikacyjnego, który ogłoszono w 1936 r. (Dz.U. z 1936 r. Nr 80, poz. 555).

71 W konstytucji z 23 kwietnia 1935 r. nie zawarto szeregu regulacji dotyczących zasad ustrojowych administracji, które znajdowały się w ustawie zasadniczej z 17 marca 1921 r. Należały do nich zasady: zespolenia, dekoncentracji, udziału czynnika obywatelskiego, unifikacji administracji rządowej i samorządowej, dwuinstancyjności, wielostopniowego sądownictwa administracyjnego. R. Hausner, Poczynania..., s. 55, oceniał, iż: „Stan ten wymaga dużej czujności ze strony ludzi, którzy w przyszłości kierować będą poczynaniami organizacyjnymi, nie brak bowiem czynników, które są krytycznie usposobione w stosunku do zasad dotychczasowych (np. zasady zespolenia)".

72 Przyjęcie konstytucji kwietniowej spowodowało, iż cała organizacja administracji rządowej została przekazana na drogę rozporządzeń prezydenckich. Miało to spowodować przyspieszenie prac legislacyjnych i skupienie całej odpowiedzialności za to zadanie w rękach rządu.

${ }^{73}$ Zob. Tamże, s. 55-57. 
The Presidential Decree of 19. January 1928

Concerning the Organization and Operation of General Administration - A Breakthrough in the Process of the Construction of the Administrative System in the Interwar Period

Summary

Presidential Decree governing organization and operation of local administration performed in the interwar period a number of important functions. It consolidated the existing system due to the separateness of the period of Poland's partition, basing it on a uniform rules. This act ordered administrative organization, clarified many of the solutions (already adopted but not developed) as well as strengthened the legal position of provincial governor (voivode) as the most important local authority. For all these reasons, Presidential Decree no doubt was a major breakthrough in the construction of Polish local administration. 